\title{
THE HYDROPHOBICITY AND ROUGHNESS OF A NASOENTERAL TUBE SURFACE INFLUENCES THE ADHESION OF A MULTI-DRUG RESISTANT STRAIN OF STAPHYLOCOCCUS AUREUS
}

\author{
Lima, J.C. ${ }^{1}$; Andrade, N.J. ${ }^{1 *}$; Soares, N.F.F. ${ }^{1}$; Ferreira, S.O. ${ }^{2}$; Fernandes, P.E. ${ }^{1}$; Carvalho, C.C.P. ${ }^{1}$; Lopes, J.P. $^{3}$; Martins, \\ J.F.L'.
}

${ }^{1}$ Departamento de Tecnologia de Alimentos, Universidade Federal de Viçosa, Viçosa, MG, Brasil; ${ }^{2}$ Departamento de Física, Universidade Federal de Viçosa, Viçosa, MG, Brasil; ${ }^{3}$ Tecnóloga em Laticínios, Viçosa, MG, Brasil.

Submitted: July 28, 2010; Returned to authors for corrections: August 30, 2010; Approved: January 13, 2011.

\begin{abstract}
In this study, we examined the physiochemical properties of nasoenteral feeding tubes made from two different types of polymer: silicone materials and polyurethane. The internal surfaces of the nasoenteral feeding tubes were analyzed for their hydrophobicity, roughness, microtopography, rupture-tension and ability to stretch. We also studied the adhesion of an isolated, multi-drug resistant strain of S. aureus to these polymers. The polyurethane nasoenteral tube, which was classified as hydrophilic, was more resistant to rupture-tension and stretching tests than the silicone tube, which was classified as hydrophobic. Additionally, the polyurethane tube had a rougher surface than the silicone tube. Approximately $1.0 \mathrm{log}$ CFU. $\mathrm{cm}^{-2}$ of $S$. aureus cells adhered to the tubes and this number was not statistically different between the two types of surfaces $(\mathrm{p}>0.05)$. In future studies, new polymers for nasoenteral feeding tubes should be tested for their ability to support bacterial growth. Bacterial adhesion to these polymers can easily be reduced through modification of the polymer's physicochemical surface characteristics.
\end{abstract}

Key words: Staphylococcus aureus adhesion; nasoenteral tubes; hydrophobicity; roughness and mechanical resistance.

\section{INTRODUCTION}

Staphylococcus aureus is a microorganism that is a common etiology of hospital infections (20, 24). S. aureus primarily residues on the mucous membranes of the human nasopharynx, as well as on human and animal skin $(15,29)$. This microbe often causes persistent and chronic infections in humans that have catheters, prostheses or other similar devices, such as feeding tubes $(3,17,25,30,35)$. These devices are often composed of polymers that can potentially support bacterial colonization, which often occurs rapidly within the first 24 hours (17). Bacterial colonization of the polymer is greatly influenced by the response of the host, such as localization of platelets, tissue proteins and plasma $(12,21)$. Microbial biofilms on medical devices are extremely difficult to treat because they are resistant to antimicrobials. For

*Corresponding Author. Mailing address: Departamento de Tecnologia de Alimentos, Universidade Federal de Viçosa, Viçosa, Minas Gerais, Brasil, 36570000.; Tel.: (+5531) 3899-2226 Fax: (+55 31) 3899-2208.; E-mail: nandrade@ufv.br 
example, nasoenteral feeding tubes are a primary risk factor for the spread of microorganisms that are resistant to multiple drugs, such as methicillin- or vancomycin- resistant $S$. aureus $(13,20,22,23)$. Antibiotic-resistant bacteria that have adhered to these devices can be transferred to other devices, causing the infection to spread rapidly among patients (23). This mode of transfer is primarily via contact of the contaminated device with the hands of nurses, which emphasizes the need for hand washing and implementation of Good Practices to Control Infections (3). However, the physicochemical properties of the polymer surface can be chemically modified to regulate bacterial adhesion (10, 14, 34, 36). Several biomaterials contain additives, such as plasticizers, stabilizers and organic polymers that improve the physicochemical properties and biocompatibility of the compound. However, these additives can be metabolized by microorganisms, thus supporting biofilm formation (28); therefore, the characteristics and composition of the polymer surface significantly influence bacterial adhesion and growth.

The objective of this study was to characterize the microtopography, hydrophobicity and resistance to biofilm formation of nasoenteral feeding tubes made of several different polymers. We simulated both open and closed feeding systems in the laboratory to study $S$. aureus adhesion and biofilm formation on nasoenteral tubes.

\section{MATERIALS AND METHODS}

\section{Physical, physicochemical and microscopic} characterization of the nasoenteral feeding tube surface The chemical and physical characteristics of the nasoenteral tubes

We studied nasoenteral feeding tubes that were made of either silicone or polyurethane $\left(\right.$ Solumed $\left.^{\circledR}\right)$; these tubes were used in Intensive Care Unit (ICU) patients who were selected to participate in this experiment. The polyurethane tube was made of dimethylsiloxane, vinyl polychloride and barium sulfate and was $120 \mathrm{~cm}$ long with an internal diameter of 3.96 $\mathrm{mm}$ and an internal area of $298 \mathrm{~cm}^{2}$. The silicone tube was made of dimethylsiloxane, vinyl polychloride, acetal-poly and barium sulfate and was $95 \mathrm{~cm}$ long with an internal diameter of $3.96 \mathrm{~mm}$ and an internal area of $238 \mathrm{~cm}^{2}$.

\section{Hydrophobicity}

Test samples $(10 \mathrm{~cm})$ were removed from the central portion of each type of tube (silicone or polyurethane); the samples were sectioned in the middle and were glued to paper. The test samples were reduced to a smaller size to improve the flatness, when necessary and samples that had flat, horizontal surfaces were used to determine the contact angle. The contact angle was determined by measuring the interior of the test samples with a goniometer (NRL A-100-00, Ramé-Hart, Mountain Lakes, NJ USA ${ }^{\circledR}$ ) and the images were analyzed at the Eloísa Mano Institute of Macromolecules (IMA) of the Federal University of Rio de Janeiro (UFRJ) (27). The contact angle measurements (at least 25 determinations) were performed with the sessile drop technique with a contact angle measurement apparatus (NRL A-100-00, Ramé-Hart, Mountain Lakes, NJ USA ${ }^{\circledR}$ ). All of the measurements were performed at room temperature $\left(25^{\circ} \mathrm{C}\right)(27)$.

\section{Atomic force microscopy evaluation of the surface topography and roughness}

Two test samples $(1.0 \mathrm{~cm})$ were removed from the central part of each tube, were sectioned in half and were sent to the Federal University of Minas Gerais, Brazil (UFMG), for atomic force microscopy (AFM) analysis. Atomic force microscopy (VEECO, Nanoscope IIIA model) was used to obtain images of the interior of the test samples with the Tapping Mode technique (24). The appropriate software for this equipment calculated the following variables: $R_{a}$, which is the arithmetic average height, and $\mathrm{R}_{\mathrm{t}}$, which is the maximum height between the highest peak and the lowest valley of the tube surface. 


\section{Determination of the rupture-tension and polymer} stretching

Seven polyurethane test samples and seven silicone test samples (10 cm in length and $3.96 \mathrm{~mm}$ in diameter) were used to determine the mechanical resistance (5), the maximum load (N) and the relative deformation at maximum load (\%). The measurements were performed with a pre-test velocity of 50 $\mathrm{mm} \cdot \mathrm{min}^{-1}$, a test velocity of $100 \mathrm{~mm} \cdot \mathrm{min}^{-1}$ and a post-test velocity of $50 \mathrm{~mm} \cdot \mathrm{min}^{-1}$ at $25^{\circ} \mathrm{C}$ and $36{ }^{\circ} \mathrm{C}$ with $1 \mathrm{kN}$ of load cells. The equipment used was a Universal Testing Machine (Instron, model 3367 Q 1126) with a maximum capacity load of $30 \mathrm{kN}$. Each sample was tested independently seven times.

\section{The Staphylococcus aureus strain}

The $S$. aureus strain was isolated from the nasoenteral tube of an ICU patient in a hospital in Viçosa, Minas Gerais. This strain was chosen because of its resistance to the antibiotics ciprofloxacin-CIP $(5 \mu \mathrm{g})\left(\mathrm{DME}^{\circledR}\right)$, amikacin-AMI $(30 \mu \mathrm{g}) \quad\left(\mathrm{DME}^{\circledR}\right), \quad$ clindamycin-CLI $\quad(2 \mu \mathrm{g}) \quad\left(\mathrm{DME}^{\circledR}\right)$, clarithromycin-CLA (15 $\mu \mathrm{g})\left(\mathrm{DME}^{\circledR}\right)$, ceftriaxone-CRO (30 $\mu \mathrm{g}) \quad\left(\mathrm{DME}^{\circledR}\right), \quad$ ceftazidime-CAZ $\quad(30 \mu \mathrm{g}) \quad\left(\mathrm{DME}^{\circledR}\right) \quad$ and sultamicillin/ampicillin (sulbactam)-APS $(10 / 10 \mu \mathrm{g})\left(\mathrm{DME}^{\circledR}\right)$. The strain is susceptible to oxacillin-OXA $(30 \mu \mathrm{g})\left(\mathrm{DME}^{\circledR}\right)$ and imipenem-IMP $(10 \mu \mathrm{g})\left(\mathrm{DME}^{\circledR}\right)(7)$.

\section{Adhesion by simulated use test}

A feeding procedure was simulated in the laboratory to mimic hospital conditions of an open enteral feeding system, where the enteral feeding device requires manipulations prior to its administration. We also used a closed system where the processed food was sterile, was packed in hermetically sealed containers and did not have prior contact with the equipment.

The tube ends were connected to two different systems. At the end where the food was administered, the tubes were connected to metallic lids, which covered glasses that collected the food after its administration; at the other end the tubes were connected to a feeding system that contained flasks that stored the food (IsoSource $\mathrm{HN}^{\circledR}$, Tetra Slim, Novartis ${ }^{\circledR}$ ) or water, which was dropped intermittently. Two polyurethane or silicone tubes were used: one tube had food with an inoculum of $1.0 \times 10^{2}$ CFU.ml ${ }^{-1}$ of $S$. aureus and a second tube (the control tube) did not have any food. The tubes and collecting flasks were incubated at $36{ }^{\circ} \mathrm{C}$ to simulate human body temperature.

Before the food was prepared, the $S$. aureus isolate was activated by incubation for $24 \mathrm{~h}$ at $37^{\circ} \mathrm{C}$ in $10 \mathrm{ml}$ of BHI broth $\left(\right.$ Merck $\left.^{\circledR}\right)$. A subsample of this strain was then inoculated into another tube that contained the same volume of medium and was incubated for $3 \mathrm{~h}$. A concentration of $1.0 \times 10^{2} \mathrm{CFU} \cdot \mathrm{ml}^{-1}$ of $S$. aureus, which is the concentration that was found in hospital food with previous analyses, was inoculated into the following food volumes: $100 \mathrm{ml}$ of food on the first day, 150 $\mathrm{ml}$ on the second day and $200 \mathrm{ml}$ on the third day. We performed these injections to simulate patient feeding in a hospital. The food was administered at $8 \mathrm{~h}, 11 \mathrm{~h}, 14 \mathrm{~h}, 17 \mathrm{~h}, 20$ $\mathrm{h}$ and $23 \mathrm{~h}$ each day for three consecutive days, for a total of 72 h. This schedule was implemented to simulate enteral food administration to ICU in-patients for three days. Administration was carried out for a maximum of $1.5 \mathrm{~h}$ and 50 $\mathrm{ml}$ of sterilized water was given at each feeding (26). The food was prepared daily at noon, was stored in flasks that were refrigerated and was removed $1 \mathrm{~h}$ before administration to allow equilibration to room temperature. The feeding system was changed every day in the morning before food administration at $8 \mathrm{~h}$. All of the material utilized was sterilized and the food, water and feeding systems were changed aseptically with a Bunsen burner. At the end of the third day, the feeding system was dismounted, and the nasoenteral tubes were fragmented for scanning electron microscopy (SEM) analysis; the tubes were also examined to quantify the number of Staphylococcus cells that had adhered to the inside. Each simulated test was performed three times for each type of tube that was tested. 


\section{Determination of the number of adhered cells}

Three test samples $(10 \mathrm{~cm})$ were removed from each tube at the beginning, middle and end portions at the end of the third day of the adhesion experiment. The interior of the three test samples was gently rinsed with a syringe and $0.6 \mathrm{ml}$ of $2 \%$ sodium citrate solution to remove any non-adherent $S$. aureus cells; the samples were subsequently vigorously rinsed with 10 $\mathrm{ml}$ of the same solution to remove the adherent cells, and this elution was collected in a sterilized Erlenmeyer flask. Aliquots $(0.1 \mathrm{ml})$ were plated in duplicate on standard agar plates (PCA, Merck $^{\circledR}$ ) and incubated at $37^{\circ} \mathrm{C}$ for $24 \mathrm{~h}$.

\section{SEM evaluation of adhesion}

Three test samples $(0.4 \mathrm{~cm})$ were excised from three portions of each tube (beginning, middle and end) immediately after the adhesion experiment ended. These portions were then segmented into four pieces by horizontal and transversal cuts in the center of the test samples. The samples were analyzed (33) with a LEO 1430 VP scanning electron microscope (Zeiss, Cambridge, England).

\section{Statistical analysis}

Variance analyses were conducted with the Statistical Analysis System (SAS). A Student's t-test was also used to analyze the results for the maximum load $(\mathrm{N})$ and deformation (\%) $\left(25^{\circ} \mathrm{C}\right.$ and $\left.36{ }^{\circ} \mathrm{C}\right)$ of each test sample and and the $S$. aureus count $\left(\log\right.$ CFU.cm $\left.{ }^{-2}\right)$ was compared between the silicone and polyurethane tubes, which were tested in triplicates and grown at $36{ }^{\circ} \mathrm{C}$. P-values $<0.05$ were considered to be statistically significant. The contact angle of the tube surface, which indicates the hydrophobicity, was analyzed as described by Adamson (1982) (1), who defined a hydrophilic surface as one with a contact angle of less than $50^{\circ}$, while a hydrophobic surface has a contact angle of greater than $50^{\circ}(1)$.

\section{RESULTS AND DISCUSSION}

The nasoenteral tubes had different contact angles with water $\left(\theta_{\mathrm{w}}\right)$ at room temperature and thus had distinct hydrophobicities: the polyurethane tube was classified as hydrophilic $\left(\theta_{\mathrm{w}}=50.2 \pm 0.61\right)$, while the silicone tube was classified as hydrophobic $\left(\theta_{\mathrm{w}}=74.6 \pm 1.30\right)$.

The different contact angles of the tubes can be attributed to the molecular structure of each material. The silicone tube has a branched chain that mainly consists of carbon, oxygen, silicone and hydrogen, which make the polymer apolar. In contrast, the polyurethane consists of benzenic rings and $\mathrm{NHCO}_{2}$ groups that confer polarity, which increases the surface interactions with water compared to silicone.

Hydrophobicity plays a fundamental role in surface adhesion and many methods are available to measure hydrophobicity. Typically, qualitative evaluation of surface hydrophobicity involves characterizing the hydrophobic or hydrophilic character of a surface by measuring the contact angle the surface with water (6). Surfaces that are hydrophobic or less hydrophilic (e.g., the tube) generally have increased adhesion (e.g., S. aureus). Removal of water film from between the tube surface and microorganisms is much easier for hydrophobic surfaces $(8,9)$. Thus, the polyurethane tube may be a better candidate because it is hydrophilic and may therefore have less bacterial adhesion.

Microtopography of the silicone tube showed that it had a mean roughness of $0.60 \mathrm{~nm}$ and was thus a smoother surface than the polyurethane tube, which had a roughness of $2.87 \mathrm{~nm}$. The maximum height between a peak and a valley also shows that the polyurethane tube surface $\left(R_{t}=53.90 \mathrm{~nm}\right)$ is rougher than the silicone $\left(R_{t}=5.63 \mathrm{~nm}\right)$. However, this information can not be analyzed separately because it can lead to a false interpretation of surface microtopography.

Figure 1 shows AFM analysis of the microtopography of the silicone and polyurethane tube surfaces; irregularities can be clearly seen on the polyurethane tube surface, while the silicone tube has small elevations, which may be inherent to the polymer surface. The microtopographs corroborate with the roughness characteristics that were previously evaluated. 

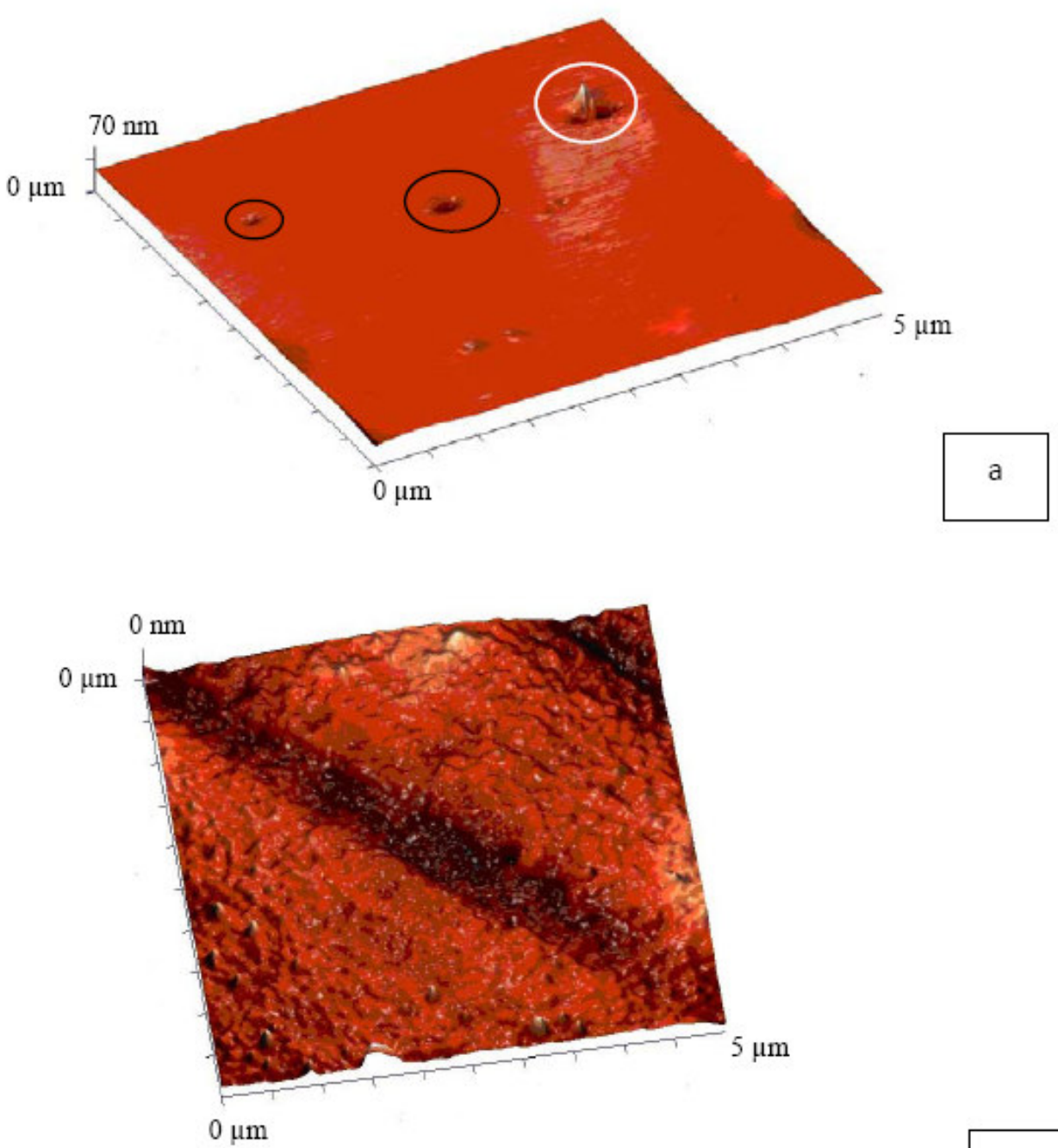

Figure 1. AFM images (surface topography) of (a) silicone tubes and (b) polyurethane tubes. The black circles show the presence of small fissures and the white circles show elevations in the silicone surface, which may be inherent to the polymer surface.

The biomaterial surface roughness is relevant to bacterial adhesion because irregularities in the polymeric surface can promote bacterial adhesion and biofilm formation $(3,14,30)$. Depressions and elevations in the surface can create a larger surface area for bacterial colonization (19) and can protect bacteria from shear forces (16). However, accumulation in these depressions depends largely on the size, cell dimension and cell cycle stage of the bacterium (18).

Only the silicone tube ruptured during the rupture-tension and polymer stretching tests. However, the relative deformation at the maximum load did not change with an increase in temperature from $25{ }^{\circ} \mathrm{C}$ to $36{ }^{\circ} \mathrm{C}$ for either of the tubes ( $p>0.05)$, although the maximum load was different for the polyurethane tube at both temperatures $(\mathrm{p}<0.05)$. The maximum load was $76.61 \mathrm{~N}$ and $172.61 \mathrm{~N}$ at $36{ }^{\circ} \mathrm{C}$ and $25{ }^{\circ} \mathrm{C}$ for polyurethane, respectively, and $25.85 \mathrm{~N}$ and $26.32 \mathrm{~N}$ for silicone, respectively.

The difference in the maximum charge of the 
polyurethane tube can be explained by the mechanical and molecular properties of the polymer. In general, the mobility of the macromolecular chain depends largely on the chemical nature and size of the flexible segments. These segments, which are created through reactions between linear and bifunctional polyols and a stoichiometric amount of diisocyanates, control the flexibility properties under low temperatures, as well as the chemical behavior of polyurethane, such as resistance to solvents, water, acids, bases and temperature. To obtain favorable elastomeric properties, especially impact resistance, the flexible segment must be amorphous and must possess a sufficiently low glass transition temperature. However, mechanical forces, combined with temperature fluctuations, can change the structure orientation and mobility within the domains of the rigid segments, especially segments that are formed from hydrogen bonding between adjacent urethane groups. During this process, the initial hydrogen bonds are broken, and more energetically favorable bonds are formed. This is followed by a change in the structure of the polymer and a change in the applied tension. Consequently, the tension is better distributed, and the material resistance increases, which contribute to increased rupture-tension, stretching, tear resistance and permanent deformations (34).

The polyurethane tube was more resistant to rupture than the silicone tube at $25^{\circ} \mathrm{C}$ and $36{ }^{\circ} \mathrm{C}$. Because if its increased resistance, we recommend polyurethane tubing for situations that may lead to tube rupture, for example, if a patient becomes aggressive and is unwilling to use the device.

After three days of simulated testing, there was no significant difference $(p>0.05)$ between the number of adhered $S$. aureus cells between the polyurethane tube (1.11 $\log$ CFU.cm ${ }^{-2}$ ) and silicone tube (0.99 log CFU.cm ${ }^{-2}$ ), although bacteria in the enteral feed were able to adhere to the internal lumen of the feeding tubes. Nasogastric tubes are a risk factor for the acquisition of multidrug-resistant organisms, including vancomycin-resistant enterococci and 1-3 methicillin-resistant
S. aureus (22, 23). According to Anderton (1999) (4), food contamination may result in bacterial colonization of the internal surfaces of the feeding tubes, the machinery and the food source.

The adherence capacity in vitro, although, does not necessarily accurately reflect bacterial adhesion to a nasoenteral tube in humans. Bacterial adherence involves complex interactions between the bacterial strain, the biomaterial surface and the host (31). For initial, non-specific bacterial cell adherence to result in a successful colonization, other specific types of adhesion are likely required.

Studies of the initial adhesion and surface growth of $S$. aureus and S. epidermidis in biomedical devices have shown that bacterial attachment to the surface depends on interactions with the host. The body initially reacts to the foreign device by forming a thrombin that is rich in fibrin and fibronectin, and then the bacteria produce a fibrous glycocalyx, known as extracellular slime, which constitutes the matrix of the biofilm (11). Moreover, bacterial adhesion and growth is influenced by the various properties of biomaterials of the foreign surface (13).

The data from this study do not show a direct correlation between the number of adhered bacterial cells, the substrate surface hydrophobicity or the roughness, as there was no significant difference $(\mathrm{p}>0.05)$ between the tube material and the number of adhered cells ( $\log$ CFU. $\left.\mathrm{cm}^{-2}\right)$.

The micrographs show that there are many irregularities in the tube surface (Figures 2), such as protuberances, fissures and orifices. Scanning electron microscopy showed the sample in two dimensions, which aided in interpretation of the bacterial adhesion results. The individual $S$. aureus cells adhered separately, but close to the food residue in the silicone tube, while the bacteria adhered proximally in the polyurethane tube. Additionally, water administration after feeding did not remove the food residue or the microorganisms that were present in the food, which resulted in S. aureus adhesion after three days (Figure 3). 

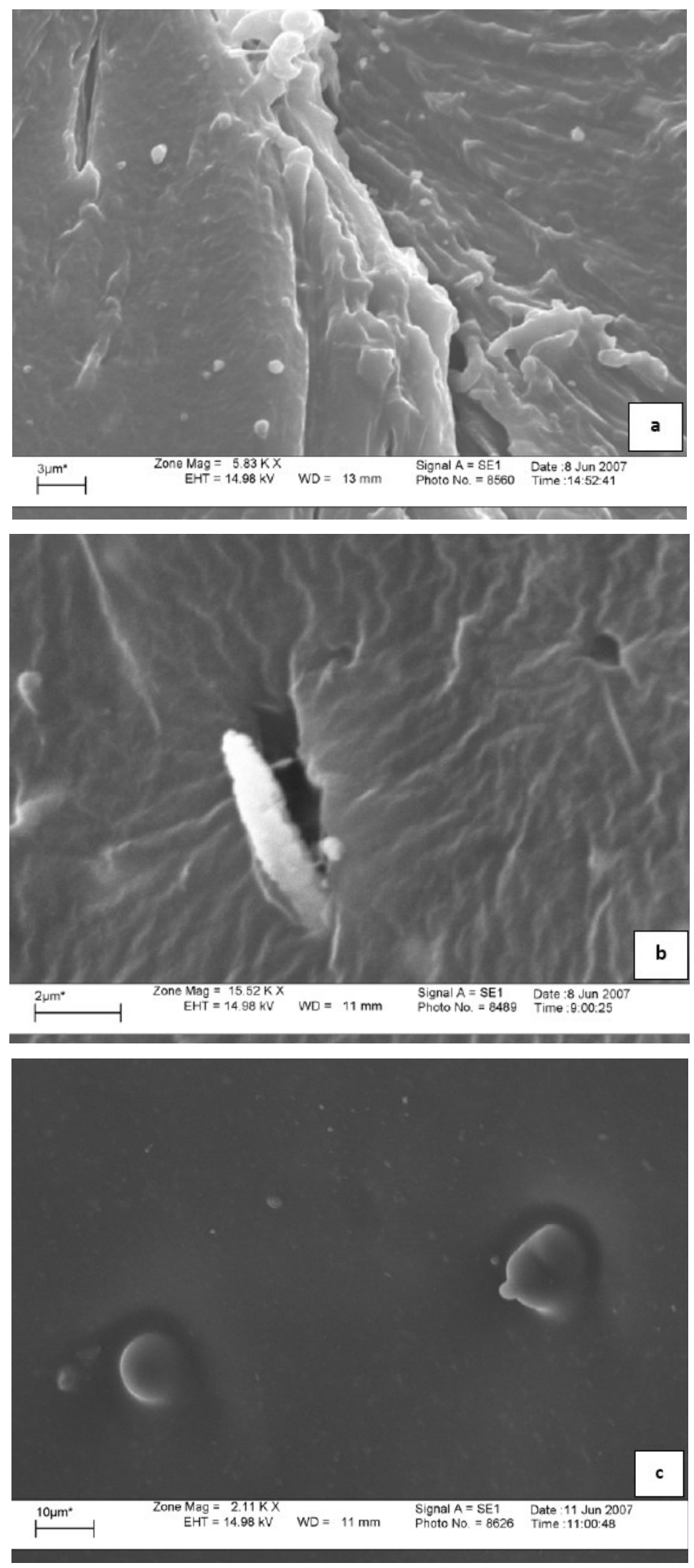


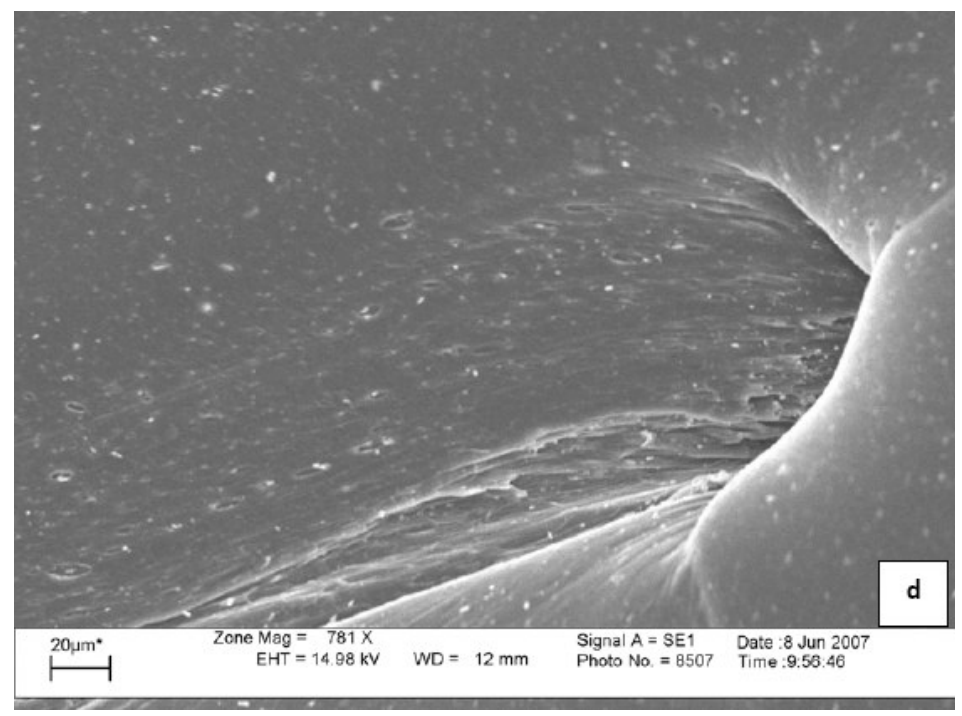

Figure 2. SEM images of the polyurethane ( $a$ and b) and silicone ( $c$ and d) tube surfaces. Irregularities, such as protuberances, fissures and orifices on the nasoenteral tube surface, can be seen;
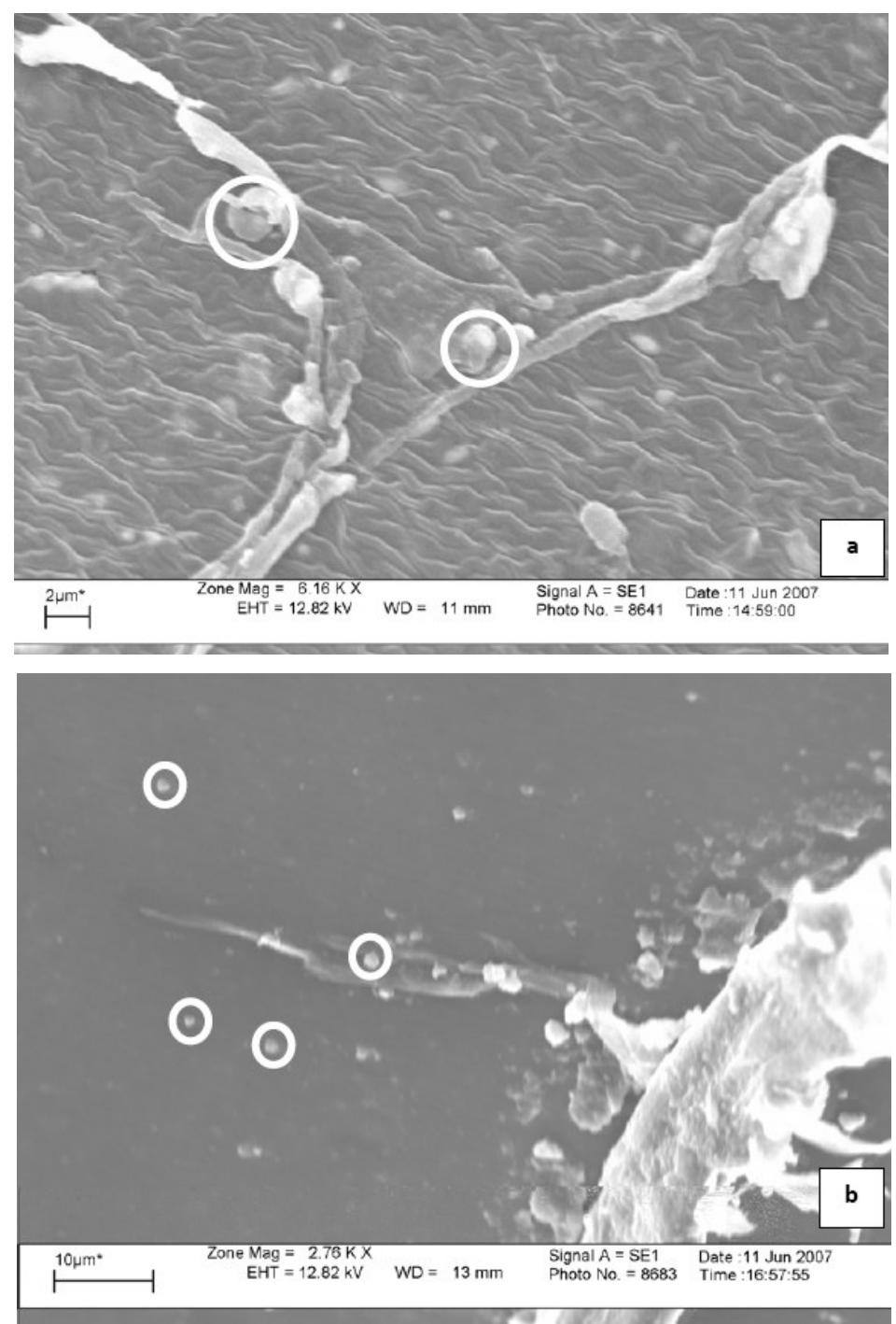

Figure 3. SEM images of $S$. aureus cells adhered to (a) polyurethane tube surfaces and (b) silicone tube surfaces after three days.456e white circles are cells that have adhered to the nasoenteric tubes. 
Anderton (1984) (2) examined internal nasoenteric tubes surfaces by SEM and observed irregularities, which can trap microorganisms; additionally, Anderton (1984) (2) discussed the potential hazards of $S$. aureus attachment to the tubing interior. Zur et al. (2004) (37) studied the internal portion of eight endotracheal tubes that were removed from neonates with electron microscopy and found adhered bacteria, including Staphylococcus, as well as biofilm formation. Biofilm formation was also observed on the external surface of all of the devices.

\section{CONCLUSIONS}

No direct relation between the surface hydrophobicity and adhesion of $S$. aureus was found in this study. The polyurethane tube, which was classified as hydrophilic, should have decreased adhesion compared to the hydrophobic silicone tube. However, microbial adhesion in the two tubes was not statistically different. Thus, microbial adhesion depends on additional polymer characteristics, such as surface roughness.

Although the polyurethane tube was hydrophilic, its surface was rougher than the silicone tube, which may have contributed to an increase in bacterial adhesion.

Flushing the tubes with sterilized water did not efficiently control pathogen colonization. Thus, food contaminated with $S$. aureus can result in colonization of polyurethane and silicone tubes and patient infection, especially in patients who are immunosuppressed. However, it is important to realize that the in vitro data may not accurately reflect the bacterial adhesion process that occurs when a nasoenteral tube is utilized by humans.

\section{ACKNOWLEDGMENTS}

The authors thank the National Council for Scientific and Technological Development (CNPq) for their supporting scholarship; the Research Foundation of the State of Minas
Gerais (FAPEMIG) for their financial support; the Federal University of Minas Gerais for their help with the atomic force microscopy; Solumed for their generous gift of the nasoenteral feeding tubes; the Eloísa Mano Institute of Macromolecules (IMA) of the Federal University of Rio de Janeiro (UFRJ) for their help with image analysis; and Claúdia Alencar Vanetti of the Nucleus for Microscopy and Microanalysis (NMM), Federal University of Viçosa (UFV), Brazil, for her technical assistance.

\section{REFERENCES}

1. Adamson, A.W. (1982). Physical chemistry of surfaces. Wiley, Interscience, New York, USA.

2. Anderton, A. (1984). Scanning electron microscopy of the internal wall topography of enteral feeding tubes. Clin. Nut. 3, 171-174.

3. Anderton, A. (1993). Bacterial contamination of enteral feeds and feeding systems. Clin. Nut. 12, 16-32.

4. Anderton, A. (1999). Enteral tube feeds as a source of infection: can we reduce the risk? Clin. Nut. 15, 55-57.

5. Association of Standard Test Method (ASTM). (2003). Test methods for vulcanized rubber and thermoplastic elastomers D412. Annual Book of ASTM Standards, 09.01.

6. Azeredo, J.C.V.R. (1998). Adesão de microrganismos e composição da matriz de bioagregados-desenvolvimento de técnicas e estudo da influência de exopolímeros. Braga, Portugal, 186 f. (D.Sc. Dissertation. Departamento de Engenharia Química e Biológica. UMinho).

7. Bauer, A.W.; Kirby, W.M.M.; Sherris, J.C.; Turk, M. (1966). Antibiotic susceptibility testing by a standardized single disk method. Am. J. Clin. Pathol. 45, 493-496.

8. Busscher, H.J.; Sjollema, J.; Van der Mei, H. (1990). Relative Importance of Surface Free Energy as a Measure of Hydrophobicity in Bacterial Adhesion to Surfaces. In: Doyle, R.J.; Rosenberg, M. Microbial cell surface hydrophobicity. American Society of Microbiology, Washington, USA.

9. Chaves, L.C.D. (2004). Estudo da cinética de formação de biofilmes em superfícies em contacto com água potável. Braga, Portugal, 186p. (M.Sc. Dissertation. Departamento de Engenharia Química e Biológica. UMinho).

10. Chen, G.; Zhu, H. (2005). Bacterial adhesion to silica sand as related to Gibbs energy variations. Colloids Surf. B. 44, 41-48.

11. Costerton, J.W.; Stewart, P.S.; Greenberg, E.P. (1999). Bacterial biofilms: a common cause of persistent infections. Science. 284, 13181322. 
12. Donlan, R.M. (2001). Biofilms and device-associated infections. Emerg. Infect. Dis. 7, 277-281.

13. Duckro, A.N.; Blom, D.W.; Lyle, E.A.; Weinstein, R.A.; Hayden, M.K. (2005). Transfer of vancomycin-resistant enterococci via health care worker hands. Arch. Intern. Med. 165, 302-307.

14. Eginton, P.A.; Gibson, H.; Holah, J.; Handley, P.S.; Gilbert, P. (1995). The influence of substratum properties on the attachment of bacterial cells. Colloids Surf. B. 5B, 153-159.

15. Fabiano, T.L.T.; Ávila, B.H.P.; Dias, C.C.; Maluta, R.P.; Ávila, F.A. (2008). Genetic similarity between Staphylococcus sp. isolated from human and hospital settings, and susceptibility to different antimicrobials. Braz. J. Microbiol. 39 (4), 652-657.

16. Fox, P.; Suidan, M.T.; Bandy, J.T. (1990). A comparison of media types in acetate fed expanded-bed anaerobic reactors. Water Res. 24, 827-835.

17. Hurrell, E.; Kucerova, E.; Loughlin, M.; Caubilla-Barron, J.; Forsythe, S.J. (2009). Biofilm formation on enteral feeding tubes by Cronobacter sakazakii, Salmonella serovars and other Enterobacteriaceae. Int. J. Food Microbiol. 136, 227-231.

18. Katainen, J.; Paajanen, M.; Ahtolaa, E.; Poreb, V.; Lahtinen, J. (2006). Adhesion as na interplay between particle size and surface roughness. $J$. Coll. Interf. Sci. 304, 524-529.

19. Katsikogianni, M.; Missirlis, Y.F. (2004). Concise review of mechanisms of bacterial adhesion to biomaterials and of techniques used in estimating bacteria-material interactions. Eur. Cell. Mater. 8, 37-57.

20. Lutz; L.; Barth, A. L. (2006). Susceptibility of Staphylococcus aureus isolates to vancomycin at a university hospital in southern Brazil. Braz. J. Microbiol. 37, 244-246.

21. Maki, D.G. (1994). Infections caused by intravascular devices used for infusion therapy: pathogenesis, prevention, and management. In: Bisno, A.L.; Waldovogel, F.A. (Ed.). Infections Associated with Indwelling Medical Devices. 2. ed. Washington: American Society for Microbiology. p. 155-212.

22. Matlow, A.; Jacobson, M.; Wray, R.; Goldman, C.; Streitenberger, L.; Freeman, R.; Kovach. D. (2006). Enteral tube hub as a reservoir for transmissible enteric bacteria. Am. J. Infect. Control. 34, 131-133.

23. Mehall, J.R.; Kite, C.A.; Gilliam, C.H.; Jackson, R.J.; Smith, S.D. (2002). Enteral Feeding Tubes Are a Reservoir for Nosocomial Antibiotic-Resistant Pathogens. J. Pediatr. Surg. 37, 1011-1012.

24. Mironov, V.L. (2004). Fundamentals of Scanning Probe Microscopy. The Russian Academy of Sciences. Nizhniy Novgorod, Russia, Institute for Physics of Microstructures.
25. Mundim, G.J.; Dezena, R.A.; Oliveira, A.C.S.; Silva, P.R.; Cardoso, M.; Pereira, G.A.; Morais, C.A.; Terra, A.P.S. (2003). Avaliação da presença de Staphylococcus aureus nos leitos do Centro de Terapia Intensiva do Hospital Escola da Faculdade de Medicina do Triângulo Mineiro, em relação à posição no colchão antes e após a limpeza. Rev. Soc. Bras. Med. Trop. 36, 685-688.

26. Neto, F.T. (2003). Nutrição clínica. Editora Guanabara Koogan, Rio de Janeiro, Brasil, p. 234-242.

27. Van Oss, C.J.; Chaudhury, M.K.; Good, R.J. (1987). Monopolar surfaces. Adv. Colloid Interface Sci. 28, 35-64.

28. Pascual, A.; Arellano, E.R.; Martinez, L.; Perea, E.J. (1993). Effect of polyurethane catheters and bacterial biofilms on the in-vitro activity of antimicrobials against Staphylococcus epidermidis. J. Hosp. Infect. 24, 211-218.

29. Resch, A.; Rosenstein, R.; Nerz, C.; Götz, F. (2004). Differential gene expression profiling of Staphylococcus aureus cultivated under biofilm and planktonic conditions. Appl. Environ Microbiol. 5, 2663- 2676.

30. Scheuerman, T.R.; Camper, A.K.; Hamilton, M.A. (1998). Effects of substratum topography on bacterial adhesion. J. Colloid Interface Sci. 208, 23-33.

31. Schmidt, H.; Schlöricke, E.; Fislage, R.; Schulze, H.A.; Guthoff, R. (1998). Effect of surface modifications of intraocular lenses on the adherence of Staphylococcus epidermidis. Zent. Fuer Bakt. 287, 135451.

32. Silveira, M. (1989). Preparação de amostras biológicas para microscopia eletrônica de varredura. In: Manual sobre técnicas básicas em microscopia eletrônica, 1 Ed. USP, São Paulo, Brasil, p.71-79.

33. Van der Mei, H.C.; van de Belt-Gritter, B.; Doyle, R.J.; Busscher, H.J. (2001). Cell surface analysis and adhesion of chemically modified streptococci. J. Colloid Interface Sci. 241, 327-332.

34. Vilar, W.D. (2004). Química e tecnologia de poliuretanos. 3 Ed. Vilar Consultoria, Rio de Janeiro. http://www.poliuretano.com.br/.

35. Vincent, J.L. (2003) Nosocomial infections in adult intensive-care units. Lancet. 361, 2068-2077.

36. Whitekettle, W.K. (1991). Effects of surface-active chemicals on microbial adhesion. J. Ind. Microbiol. Biotechnol. 7, 105-116.

37. Zur, K.B.; Mandell, D.L.; Gordon, R.E.; Holzman, I.; Rothschild, M.A. (2004). Electron microscopic analysis of biofilm on endotracheal tubes removed from intubated neonates. Otolaryngology - Head and Neck Surgery. 130, 407-414.

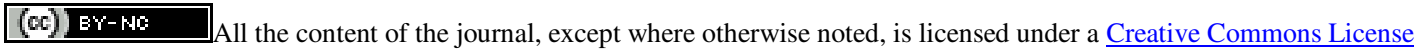

